\title{
Reducing Homophobia Within The College Community
}

\author{
Rosemary Iconis, Queensborough Community College of the City University of New York, USA
}

\begin{abstract}
Research over the last two decades reveals widespread anti-gay prejudice on many college campuses. Faculty can improve the climate for lesbian and gay students in our classes and on our campuses in a number of ways.
\end{abstract}

Keywords: Gay, Lesbian, Homophobia, College Community

\section{INTRODUCTION}

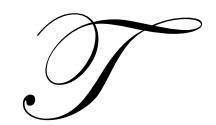

he college campus might be described as a place dedicated to the free and respectful exchange of ideas. We might think of it as a community in which harassment, intimidation and violence are not tolerated. Unfortunately, many studies of college climate demonstrate that this is not the case for lesbian, gay and bisexual students (Rankin, 1998). How we, as college faculty address - or fail to address - issues of sexual orientation in and out of our classrooms has a significant impact on the learning environment for all of our students, but especially for those who identify as lesbian, gay or bisexual. By supporting academic inquiry into sexual-orientation topics and creating a welcoming campus environment for all students, faculty contribute not only to the academic success of our students, but also to the development of a positive self-identity. Conversely, by engaging in or being oblivious to homophobic harassment or discriminatory behavior, we perpetuate negative stereotypes, validate the hatred perpetrated against lesbian, gay and bisexual (LGB) individuals, and interfere with learning (Renn, 2000).

\section{HOMOPHOBIA ON THE COLLEGE CAMPUS}

Two of the most consistent findings in attitude research have been that heterosexuals' attitude towards lesbians and gay men are negative and that American society finds this negativity to be acceptable. Whether conducted using samples of college students (Herek, 1984, 1986; Kite, 1994) or national survey samples (Herek \& Capitanio, 1996; Herek \& Glunt, 1993), the research reveals widespread anti-gay prejudice (Loviderback \& Whitley, 1997).

In considering negative attitudes, it is necessary to differentiate between prejudice and discrimination. Some college students and faculty alike have prejudices and stereotypes about lesbians and gay men, but they do not necessarily act on the prejudices in a manner that would interfere with their rights (Sanio 1998; Lance, 2002). However, it has been well documented that lesbian and gay students experience significant negative consequences from being exposed to violence and harassment on campus (D'Augelli \& Rose, 1990; NGLTF Policy Institute, 1993). The University of Minnesota Select Committee on Lesbian, Gay and Bisexual Concerns (1993) reported that in both written testament and public hearings, undergraduate and graduate students described the 'humiliating and demeaning' environments in which they were expected to function both in and out of the classroom. The students reported occasions when faculty made derogatory jokes, made hostile and demeaning comments, and even implied that violence directed against lesbians and gay men is justified (University of Minnesota, 1993, Renn, 2000).

In 1989, The Faculty Committee on the Status of Sexual Minorities at Brown University (Brown University Faculty Committee, 1989) reported that $66 \%$ of lesbian and gay students feared harassment or discrimination by classmates and $40 \%$ feared harassment or discrimination by professors. In the Brown University Report $10.5 \%$ of respondents reported occasionally hearing faculty make negative remarks or jokes that demean lesbians and gay men. 


\section{FACTORS CONTRIBUTING TO ANTI-GAY PREJUDICE}

Herek $(1984,1991)$ and others (Herek \& Capitano, 1996; Herek \& Glunt, 1993; Loviderback \& Whitley Jr., 1997) have uncovered a number of factors associated with anti-gay prejudice. For example, people who hold negative attitudes towards lesbians and gay men are typically more traditional in their sex-role attitudes, less well educated and more negative towards members of other minority groups than are their less prejudiced peers.

Research on the factors associated with attitudes toward lesbians and gay men has shown that heterosexual men hold more negative views than heterosexual women. In an analysis of studies of the relationship between sex of respondents and attitudes toward lesbians and gay men, Kite and Whitley (1996) found that men were more negative than women when rating gay men, but there were no sex differences in the ratings of lesbians. Women made approximately equal ratings of lesbians and gay men.

Though there are few studies in the area, some research has suggested that lesbianism has erotic value for at least some heterosexual men (Reiss, 1986). This positive erotic value assigned to lesbianism may counteract the stigma associated with homosexuality, resulting in attitudes of heterosexual males toward lesbians that are less negative than those toward gay men. With the level of erotic value controlled, men's attitudes towards lesbians are virtually identical with their attitudes toward gay men (Loviderback \& Whitley Jr., 1997). Women are less likely to sexualize men in the same way. Since there is no modifying influence on women's attitudes towards lesbians versus gay men, they hold similar attitudes toward members of both groups (Kite \& Whitely, 1996).

\section{CHALLENGING INTOLERANCE}

Prejudice and discrimination against lesbian and gay students, faculty and staff is often intensified by a lack of knowledge and understanding between heterosexuals and the LGB community. A small number of programs exist at private and public institutions which are designed to improve relations between heterosexuals and the LGB community. One such program, "Rainbow Visibility," is a comprehensive project at a private university that aims to raise campus awareness about homophobia and to educate the university community on lesbian and gay culture and history (Getz \& Kirkley, 2006). The goal is to move the campus community toward inclusion of its own LGB community. At the time of the inception of the program, the climate was very unstable for the lesbians and gays on campus. Faculty and staff feared losing their jobs if they came out and students risked harassment and violence.

The program began with a small group (between 12 and 18) of students, staff, faculty, administration and alumni, who gave presentations and workshops on sexual orientation and other diversity issues. Interactive presentations focused on areas such as stereotypes, religious issues, political issues and hate crimes. Postpresentation evaluations indicated that the presentations contributed to a positive change in campus climate toward greater inclusion of lesbians and gay men in the college community.

As people begin to understand discrimination, they begin to recognize, acknowledge and confront their own biases (Tatum, 1992). Programs like Rainbow Visibility provide heterosexual, lesbian and gay individuals the opportunity to engage with one another in an atmosphere of collaborative teaching and learning (Getz \& Kirkley 2006).

\section{WHAT FACULTY CAN DO}

Faculty can improve the climate for lesbian and gay students in our classes and on our campuses. First, we must examine our own biases, which may be conscious or unconscious. Next, we must be proactive.

While overt victimization is an obvious problem, lesbian and gay students also experience discrimination when faculty take a passive stance. Faculty can help to create a welcoming environment for all students in the following ways: 
- $\quad$ Teach to Reduce Victimization of Lesbian, Gay, and Bisexual People

- Recognize and interrupt homophobic harassment when it occurs

- Create a classroom climate that supports dialogue, debate, and disagreement within a context of personal respect

- Refrain from anti-LGB jokes, derogatory remarks, and personal attacks on students

- Call prompt attention to both malicious and unintended homophobic remarks by students

- $\quad$ Increase Visibility of LGB Issues and People

- Support visible LGB faculty and staff as role models for students

○ Incorporate LGB material in the curriculum of "mainstream" courses

○ Support the development of LGB studies curricula

- $\quad$ Support Students in their Academic Exploration of LGB Issues

- Encourage all students to research and write about issues affecting the lesbian and gay communities

- Learn more about lesbian and gay issues by attending campus events, as well as related sessions at academic conferences (Renn, 2000)

${ }^{1}$ the abbreviation LGB (or some variation, such as GLB), is often used to avoid the need to repeatedly enumerate the groups included under the rubric of non-heterosexual.

\section{CONCLUSION}

Through our own teaching, service and scholarship, college faculty can help to create a more tolerant campus community. By improving the climate for lesbian, gay and bisexual students in our classes and on our campuses, we can contribute to the academic success and personal development of all of our students.

\section{AUTHOR INFORMATION}

Dr. Rosemary Iconis is currently an Associate Professor at Queensborough Community College of the City University of New York. She is an award winning lecturer whose papers have been presented both nationally and internationally. Accomplished as a writer and researcher, Dr. Iconis has published extensively for newspapers and magazines on topics related to the health of both children and adults.

\section{REFERENCES}

1. Brown University Faculty Committee on the Status of Sexual Minorities. (1989). Lesbian, gay, and bisexual students on the Brown University campus: A study in progress. Providence, R. I.

2. D'Augelli, A.R. \& Rose, M.L. (1990). Homophobia in the university community: Attitudes and experiences of heterosexual freshmen. Journal of College Student Development, 31, 484-91.

3. Getz, C. \& Kirkley, E. (2006). Shaking up the status quo: Challenging intolerance of the lesbian, gay and bisexual community at a private Roman Catholic university. College Student Journal, 4, Issue 4, 857+.

4. Herek, G.M. (1984). Beyond "homophobia": A social psychological perspective on attitudes toward lesbians and gay men. Journal of Homosexuality, 10, 1-21.

5. Herek, G.M. (1986). On heterosexual masculinity: Some psychical consequences of the social construction of gender and sexuality. American Behavioral Scientist, 29, 563-577.

6. Herek, G.M. (1991). Stigma, prejudice and violence against lesbians and gay men. In J.C. Gonsiorek \& J.D. Weinrich (Eds.), Homosexuality: Research implications for public policy (pp. 60-80). Newbury Park, CA: Sage.

7. Herek, G.M. (1994). Assessing heterosexuals' attitudes toward lesbians and gay men: A review of research with the ATG L. scale. In B. Greene \& G.M. Herek (Eds). Lesbian and gay psychology: Theory, research, and clinical applications. (pp. 206-228). Thousand Oaks, CA: Sage.

8. Herek, G.M. \& Capitanio, J.P. (1996). "Some of my best friends": Intergroup contact, concealable stigma, and heterosexuals' attitudes toward gay men and lesbians. Personality and Social Psychology Bulletin, 22, 412-424. 
9. Herek, G.M.\& Glunt, E.K. (1993). Interpersonal contact and heterosexuals' attitudes towards gay men: Results from a national survey. The Journal of Sex Research, 30, 239-244.

10. Hort, B.E., Fagot, B.I. \& Leinbach, M.D. (1990). Are people's notions of maleness more stereotypically framed than their notions of femaleness? Sex Roles, 23, 197-212.

11. Kite, M.E. (1994). When perceptions meet reality: Individual differences in reactions to lesbians and gay men. In B. Greene \& G.M. Herek (Eds.), Lesbian and gay psychology: Theory, research, and clinical applications (pp. 25-53). Thousand Oaks, CA: Sage.

12. Kite, M.E. \& Whitley, B.E. Jr. (1996). Sex differences in attitudes toward homosexual persons, behaviors and civil rights: A meta-analysis. Personality and Social Psychology Bulletin, 22, 336-352.

13. Lance, L. (1984). Heterosexism and homophobia among college students. College Student Journal, 36, Issue 3, 410+.

14. Loviderback, L. \& Whitley, B.E. Jr. (1997). Perceived erotic value of homosexuality and sex role attitudes as mediators of sex differences in heterosexual college students' attitudes toward lesbians and gay men. The Journal of Sex Research, 34, Issue 2, 175+.

15. National Gay and Lesbian Task Force (NGLTF). Policy Institute. (1993) Anti-gay/lesbian violence, victimization and defamation in 1992. Washington, D.C.

16. Rankin (1998). The campus climate report: Assessment and intervention. In R. Sanio (Ed.) Working with lesbian, gay, bisexual, and transgender college students: A handbook for faculty and administrators. Westport, Conn: Greenwood (http://www.uic.edu/orgs/lgbt).

17. Reiss, I.L. (1986). Journey into sexuality: An exploratory voyage. Englewood Cliffs, NJ: Prentice Hall.

18. Renn, K. A. (2000). Including all voices in the classroom. College Teaching, 48, Issue 4.

19. Sanio, R. (Ed.) (1998). Working with lesbian, gay, bisexual, and transgender college students: A handbook for faculty and administrators. Westport, Conn.: Greenwood

20. Tatum, B. (1992). Talking about race, learning about racism: The application of racial identity development theory in the classroom. Harvard Educational Review, 62, Issue 1.

21. University of Minnesota Select Committee on Lesbian, Gay, and Bisexual Concerns. (1993). Breaking the Silence. Minneapolis/St. Paul. 